\title{
Effects of Differential Instruction Upon the Creative Response of Deaf Students
}

$$
\text { Carolyn Kampe }
$$

The study focused upon three questions: (1) Did differences exist in cognitive and creative abilities between deaf individuals and hearing individuals in the third through sixth grades? (2) Were deaf individuals, due to their lack of auditory input, disadvantaged in learning to process visual information? (3) Did the responses of deaf and normal hearing individuals receiving both oral and manual instruction differ from those individuals receiving only written instruction on Silver's (1983) Drawing What You Predict, What You See, and What You Imagine test and Torrance's (1966) Thinking Creatively With Pictures test. The review of related literature revealed that no research specifically relating mode of communication to functioning of deaf students in art education was available. However, the studies which peripherally related to this study were categorized into six groups: historical, sign language, schools for deaf, manual, total communication, and other forms of communication.

Historically, deaf persons were thought to be incapable of learning. The only education they received was related to handling private business affairs and, even then, only wealthy deaf persons were educated. Michael De L'Epee was believed to be the first teacher of deaf children. His.school used sign language. From this point, schools for deaf persons developed throughout France, Germany and, eventually, the United States. Each country developed its own philosophies for teaching deaf persons.

The various philosophies developed from each country's experience with the deaf population and from the varied methods of communication. All philosophies fall into one of three broad categories: (1) aural/oral method, which utilizes all methods of the oral system plus auditory training; (2) oral only method, which utilizes speech only -- no manual communication; and (3) total communication, which utilizes all forms of communication. Additionally, there are many different forms of communication (see Appendix A).

Three studies were reviewed that discussed art and hearing impaired/deaf persons. In each case, the tests used to determine creative ability did not require verbal skills. The results of these studies indicated that deaf persons are more like hearing persons in art abilities than was previously believed. Furthermore, two other studies that Investigated the effects of method of communication on scores of deaf children on the performance scale of the Weschler Intelligence Scale Children - Revised (WISC-R) and on a standardized vocabulary test concluded that the method of communication significantly affected the scores of students.

Working Papers in Art Education 1989 - 1990 
This investigation was conducted in six elementary schools located in central and northwestern Illinois. Seventy-nine elementary school subjects in grades three through six were included in the study. Of the 79 subjects, 40 were normal hearing subjects and 39 were deaf subjects. The 79 subjects were assigned to one of four groups. Groups I and II consisted of deaf subjects. Groups III and IV consisted of normal hearing subjects. All groups included male and female subjects of chronological ages usually found in grades three through six. Silver's Drawing What You Predict, What You See, and What You Imagine test, consisting of three categories - "Predictive Drawing," "Drawing from Observation," and "Drawing from Imagination" -- was administered on a pretest and posttest basis for all groups. Torrance's Thinking Creatively With Pictures test, consisting of four parts -- "Scoring Picture Construction," "Picture Completion," "Parallel Line" and "Summarizing the Results" -- was also administered on a pretest and posttest basis to all groups.

The subjects' treatment consisted of three experimenter-created art lessons which presented information on overlapping, size, vertical location, horizontal lines, composition, and detail. Following the treatments, the subjects completed a posttest which consisted of the Silver Test and the Torrance test.

Group I was given a pretest using the modified Torrance test, Thinking Creatively With Pictures, and the modified Silver. test, Drawing What You Predict, What You See, and What You Imagine, using total communication. Group II was given a pretest comprised of these two tests administered using written communication only. Group III was given the same pretests using modified versions of Torrance's Thinking Creatively With pictures and Silver's Drawing What You Predict, What You See, and What You Imagine, using total communication. Group IV received both pretests using written communication. All pretests were administered on day 1.

Experimental treatments were presented to Groups I, II, and III on days 2, 3, and 4 of the study. Group IV received no treatment. Posttests were administered to all groups on day 5 .

The study attempted to determine which of two experimental treatments had the most effect upon creative abilities. Total communication or written instruction were used with both deaf and normal hearing subjects. The results of the data collected were subjected to statistical analyses. The alpha for the study was established at .05 . The hypotheses that had been generated were tested in their null form using the SPSS-X statistical package (SPSS-X, Inc., 1988).

An overall analysis of the two treatments and a review of the statistical analysis of data collected indicated that few differences existed between deaf and normal hearing subjects regardless of treatment. Except for the individual subtests discussed in the data analysis of each hypothesis, no significant differences between groups were found. When given meaningful 
communication modes, deaf subjects achieved on a level equal to their hearing peers. Through use of total communication, subjects for whom input was through non-auditory modes matched their peers in creative production.

Two hypotheses were established to determine the existence of correlation between the Torrance and Silver pretests and the Torrance and Silver posttests. A stronger correlation (15 correlations out of a possible 25) was found to exist between the Torrance and Silver posttest. This would indicate that the two tests were consistently measuring some behavior. From the analysis of data, it was observed that the pretest scores between Torrance and Silver were not related to each other (5 out of 25 factors) as were the posttest scores (15 out of 25). This would indicate that something did indeed occur between the pretest session and the posttest session.

A summary of the results of the statistical analysis of each hypothesis follows:

1. Research Hypothesis I stated: There will be significant differences on creative scores between deaf subjects and normal hearing subjects in the third through sixth grades as measured by the Torrance and Silver posttests. This hypothesis, when tested in the null form, failed to be rejected with confidence.

2. Hypothesis II stated: There will be a significant difference in scores on the Torrance and Silver pretests between those groups assigned to total communication and those groups assigned to written communication. This hypothesis, when tested in the null form, failed to be rejected with confidence.

3. Hypothesis II stated: There will be a significant difference in scores on the Torrance and Silver posttests between groups receiving total communication and groups receiving written communication. This hypothesis, when tested in the null form, failed to be rejected for the Torrance and Silver posttests.

4. Hypothesis IV stated: There will be a significant difference in scores on the Torrance and Silver posttests between deaf subjects and normal hearing subjects exposed to total communication treatment. This hypothesis, when tested in the null form, failed to be rejected with confidence for the Torrance and Silver posttests.

5. Hypothesis $V$ stated: There will a larger gain score between Torrance pretest and posttest by subjects exposed to total communication treatment. This hypothesis, when tested in the null form, failed to be rejected with confidence.

Working Papers in Art Education 1989 - 1990 
6. Hypothesis VI stated: There will be a larger gain score between Silver's pretest and posttest by subjects exposed to total communication treatment. This hypothesis, when tested in the null form, failed to be rejected with confidence.

7. Research Hypothesis VIi stated: There will be found to exist a relationship between the Torrance posttest and the Silver posttest. An analysis of the correlation coefficient for the Torrance posttest and Silver posttest scores showed that there were 15 significant correlations out of a possible 25 .

8. Research Hypothesis VIII stated: There will be found to exist a relationship between the Torrance Pretest and the Silver pretest. Five significant correlations were found. From the analysis of data it was observed that the pretest scores between Torrance and Silver were not related to each other (5 out of 25 factors).

It is reasonable to conclude that hearing impaired (deaf) students may achieve in art when grouped with normal hearing students and when given access to full information with total communication modes. Teachers, therefore, should either be skilled in providing all communication modes or be assisted by interpreters to provide modes for students who are deaf.

A review of the data from this study indicated that more research needs to be conducted to determine the effects of various communication methods upon the creative art abilities of deaf subjects. Recommendations for future research in areas of deaf education should concentrate upon several premises.

The most important recommendations are those that involved changes and adaptions in the test instruments and the experimental sessions. It is imperative that test instruments be normed with a deaf population to allow for accurate information gathering and the setting of standards. Furthermore, perceptual tests or spatial relation tests should be included in the battery to define more clearly creative abilities. Regarding the experimental sessions, this researcher believes any treatment sessions used should be investigated to determine relationships of perceptual and creative abilities. In light of the findings, the experimental sessions should be modified to increase the subjects' opportunities to relate to the skills being measured.

\section{References}

Alexander, K. (1978). Forgotten aspects of total communication. American Annals of the Deaf, 123 (1), 18-21.

Anderson, F. (1983, October). A critical analysis of a review of the published research literature in art for the handicapped: 1971- 
1981, with special attention to the visual arts. Alexandria, VA: American Art Therapy Association.

Baker, H. (1944). Introduction to exceptional children. New York: Macmillan Company.

Berg, F., \& Fletcher, S. (1970). The hard of hearing child; Clinical and educational management. New York: Grune \& Stratton.

Carver, R. (1988). Social factors in the development of the deaf child. Association of Canadian Educators of the Hearing Impaired (ACEHI) Journal, 14 (2).

Cokely, D. (1979). Pre-college programs: guideline for manual communication. Washington, DC: Gallaudet College.

Crittenden, J.; Ritterman, S., \& Wilcox, E. (December, 1986). American Annuals of the Deaf, 31 (5), 356-60.

Davis, S. J., \& Riehm, C. L. (1980, August). Art and the handicapped. Virginia Department of Education. (ERIC Document Reproduction Service No. ED 233 508)

Davis, H., \& Silverman, S. R. (1970). Hearing and deafness. New York: Holt, Rinehart, \& Winston.

Evans, L. (1982). Total communication. Washington, DC: Gallaudet College Press.

Feldman, H. (1970). A history of audiology. New York: Columbus University Press.

Furth, Hans G. (1973). Deafness and learning. A psychosocial approach. Belmont, CA: Wadsworth Publishing Company, Inc.

Furth, H. (1966). Thinking without language. New York: Free Press.

Gannon, J. R. (1981). Deaf heritage: A narrative history of deaf America. Silver Springs, MD: National Association of the Deaf.

Green, D. (1976). An introduction to hearing. Hillsdale, NJ: Lawrence Erlbaum Associates, Inc.

Griffith, J. (1969). Persons with hearing loss. Springfield, IL: C. C. Thomas.

Heimgartner, N. L. (1982). Behavioral traits of deaf children. Springfield, IL: C. C. Thomas. 
Hodgson, K. (1954). The deaf and their problems; A study. New York: Philosophical Library.

Illinois State Board of Education. (1980, July). Hearing impaired manual: Recommended procedures and practices. Springfield, IL: ISBE.

Kenny, V. (1962) A better way to teach deaf children. Harper's Magazine, 224 (1342), 61.

Kryter, K. D. (1970). The effects of noise on man. New York: Academic Press.

Levine, E. S. (1981) The ecology of early deafness. New York: Columbia University Press.

McEntee, M. (1981). The right to heritage: The teaching of deaf history. (Vols. 126-4). American Annals of the Deaf, 126 (4), 402.

Martin, F. (1987). Hearing disorder in children. Austin, TX: PRO-ED, Inc.

Mitchell, J. V., Jr. (Ed.). (1985). The Ninth Mental Measurement Yearbook, Vol. 2, 714, Index. Lincoln, NB: University of Nebraska Press.

Moores, D. (1970). Educating the deaf, psychology, principles, and practices. Boston: Houghton Mifflin Company.

Myklebust, H. R. (1960). The psychology of deafness sensory deprivation, learning, and adjustment. New York:: Grune \& Stratton.

Pahz, J. \& Pahz, C. (1978). Total communication: The meaning behind the movement to expand educational opportunities for deaf children. Springfield, IL: Charles C. Thomas.

Pinter, R. (1941, May). Artistic appreciation among deaf children. American Annals of the Deaf, 86 (3), 218-224.

Quigley, S., \& Kretschmer, R. (1982). The education of deaf children. Baltimore, MD: University Park Press.

Rainer, J. (1969). Family and mental health problems in a deaf population. Springfield, IL: Charles C. Thomas.

Reed, M. (1984). Educating hearing-impaired children: In ordinary and special school. England: Milton Keynes.

Shectman, A. (Ed.). (1981). Insight art in special education: Educating the handicapped through art. Millburn, NJ: Art Educators of New Jersey.

Working Papers in Art Education 1989 - 1990 
Silver, R. (1983). Drawing what you predict, what you see, and what you imagine. Seattle, WA: Special Child Publications.

Silver, R. (1983). Silver drawing test of cognitive and creative skills. Seattle, WA: Special Child Publications.

SPSS-X, User's Guide, 3rd ed. (1988). Chicago: McGraw-Hill Book Company.

Sullivan, P. (1982, October). Administration modifications on the WISC-R performance scale with different categories of deaf children. American Annals of the Deaf, 27 (6), 780-88.

Torrance, P. (1962). Thinking creatively with pictures. Figural Booklets A \& B. Bensenville, IL: Scholastic Testing Service, Inc.

Torrance, P. (1966). Torrance test of creative thinking. Bensenville, IL: Scholastic Testing Service, Inc.

Vernon, M. (1972, December). Mind over mouth: A rationale for total communication: Volta Review, 74, (2), 529-40.

Wilbur, R. (1979). American sign language and sign systems. Baltimore, MD: University Park Press. 